\title{
Роль звивистої конфігурації коронарних артерій у виникненні клінічних проявів ішемічної хвороби серця
}

\author{
Лебедєва $\epsilon .{ }^{1}{ }^{1}$, Груша М. М. ${ }^{2}$ \\ ${ }^{1}$ ДУ «Національний інститут серцево-судинної хірургії імені М. М. Амосова НАМН» (Київ) \\ ${ }^{2}$ Національний медичний університет імені О. О. Богомольця (Київ)
}

\begin{abstract}
У статті розглянуто роль звивистої конфігурації коронарних артерій (КА) у виникненні клінічних проявів ішемічної хвороби серця (IXC) у пацієнтів із відсутніми ангіографічними ознаками атеросклеротичного ураження стінки вінцевих судин і з різним ступенем коронарного стенозу. Представлено результати загальноклінічного, електрокардіографічного та стрес-вектор-ехокардіографічного обстеження таких пацієнтів. Наведено докази значущості звивистої конфігураційної аномалії КА у розвитку клінічних проявів ішемії міокарда за умови відсутності та наявності ангіографічних ознак гемодинамічно значущого атеросклерозу коронарних судин. Продемонстровано роль звивистості КА в порушенні коронарної гемодинаміки, зменшенні функціональних резервів серцевого м'яза та появі клінічних проявів ішемії міокарда, що необхідно враховувати в ранній діагностиці різних форм IXC.
\end{abstract}

Ключові слова: ішемічна хвороба серия, звивистість коронарних артерій, порушення коронарної гемодинаміки.

Ішемія міокарда є результатом порушення рівноваги між коронарним кровотоком і метаболічними потребами серцевого м'яза. 3 огляду на функціональні резерви коронарного русла, сучасна патофізіологічна модель ішемії міокарда, стенокардії напруження і розвитку ішемічної хвороби серця (IXC) грунтується на появі гемодинамічної значущості атеросклеротичного ураження судинної стінки коронарних артерій (КА). У зв’язку з останнім діагностика та лікування IXC зосереджено на виявленні та усуненні стенозу вінцевих судин [1-3]. Проте при проведенні діагностичних і лікувальних процедур, серед яких провідне місце належить коронаровентрикулографії (КВГ), у 15-30\% пацієнтів із типовою клінічною картиною IXC ангіографічні ознаки атеросклеротичного ураження КА або гемодинамічно значущого стенозу не виявляються [4, 5]. Водночас у частини таких пацієнтів були виявлені конфігураційні аномалії вінцевого русла у вигляді звивистості КА [5, 6].

Дані ангіографічного дослідження вказують на наявність такого конфігураційного феномену в 9,2$42,7 \%$ пацієнтів різних популяційних груп $[4,5]$, а експериментальні та клінічні дослідження свідчать про вплив цієї конфігурації судин на ефективність перфузії міокарда [4-8]. Результати експериментальних досліджень коронарного русла узгоджуються з даними, отриманими при дослідженні етіології ішемічних процесів у зонах васкуляризації звивистими судинами інших артеріальних басейнів [3, 9], проте досі не знайшли достатнього відображення в клінічній практиці. Останнє зумовлено сконцентрованістю діагностики та вибору тактики лікування IXC залежно від гемодинамічної значущості атеросклеротичного ураження стінки КА та визначення тяжкості коронарного атеросклерозу (АТC). Однак факт відсутності стенозуючого АТС KA може призвести до помилок у діагностиці IXC, загальному прогнозі для пацієнтів зі звивистими КА та відмови кардіологів від заходів вторинної профілактики IXC та диспансерного обліку таких пацієнтів.

3 огляду на викладене, метою роботи було дослідження ролі звивистої конфігурації КА у виникненні клінічних проявів IXC.

Матеріали та методи. У дослідження було включено 1404 пацієнти з клінічними проявами IXC, серед яких, за даними КВГ, 588 мали звивисту конфігурацію КА. Серед пацієнтів переважали чоловіки $(76,1 \%)$; вік пацієнтів коливався в межах від 26 до 88 років.

За результатами КВГ, а саме - за наявності звивистої конфігурації КА, візуальних ознак атеросклеротичного ураження судинної стінки та його гемодинамічної значущості пацієнти були розподілені на чотири групи. Першу групу (ЗКА) складали хворі зі звивистими КА без ангіографічних ознак атеросклеротичного ураження судинної стінки $(\mathrm{n}=252)$. До другої групи (3КА ${ }^{\mathrm{ATC} \leq 50 \%}$ ) ввійшли пацієнти зі звивистими КА при наявності в них звуження, що не перевищувало $50 \%$ діаметра просвіту судини $(\mathrm{n}=92)$. До третьої групи (3КА АТС $>50 \%)$ ввійшли пацієнти зі звивистими КА, у яких стеноз перевищував 50\% діаметра просвіту судини $(\mathrm{n}=244)$. Четверту групу (НЗК $\left.{ }^{\mathrm{AATC}>50 \%}\right)$ становили пацієнти з незвивистими КА, у яких стеноз перевищував $50 \%$ діаметра просвіту судини $(n=816)$. 
Звивистими вважали КА з трьома і більше вигинами з величиною деформації відносно прямолінійної осі $\geq 45^{\circ}$, визначених у систолу і діастолу [6].

В дослідженні були використані такі методи обстеження пацієнтів: загальноклінічні, електрокардіографія (ЕКГ), велоергометрія, КВГ, фармакологічна стресвектор-ехокардіографія (стрес-ВЕхоКГ), статистичні.

КВГ проводилася за допомогою апаратів «COROSCOP TOP», «AXIOM Artis», «TOSHIBA» за стандартними методиками: трансфеморальним, рідше трансрадіальним доступом. Фармакологічна стресВЕхоКГ проводилася на апараті «Vivid E9» (General Electric, США) з використанням інтегрованого програмного забезпечення XStrain, згідно зі стандартними методиками. Дослідження виконували відповідно до стандартного протоколу проведення медикаментозної стрес-ехокардіографії, із внутрішньовенним введенням добутаміну (Добутрекса ${ }^{\circledR}$ ) «Nycomed» у дозах 5-10-2030 та 40 мкг/кг/хв. за східчасто-зростаючою схемою, із 3 -хвилинною тривалістю кожної стадії. Аналіз результатів проводили на основі вивчення систолічного поздовжнього стрейну, вимірюючи його сегментарні значення в сегментах лівого шлуночка відповідно до класифікації Американського товариства ехокардіографії [10].

Статистичний аналіз результатів дослідження проводився за допомогою програми SPSS 16.0 for Windows.

Результати та обговорення. Пацієнти зі звивистими KА кожної з досліджуваних груп зазначали наявність у них больового синдрому, який істотно обмежує їх фізичну активність. Частота виникнення больового синдрому в групі 3КА становила $100 \%$, що є статистично значуще $(\chi$ $2=25,93$; $=0,005)$ вищим за його появу в інших досліджуваних групах (3КА ${ }^{\mathrm{ATC} \leq 50 \%}-86 \%$, 3КА ${ }^{\mathrm{ATC}>50 \%}-92 \%$, H3КААтС $>50 \%$ - 93\%). Визначення у пацієнтів функціонального класу (ФК) стенокардії напруження $(\mathrm{CH})$ виявило дві протилежні тенденції: зменшення частоти прояву СН ФК2 і збільшення частоти прояву СН ФК3 зі збільшенням ступеня атеросклеротичного ураження стінки КА (табл. 1).

Отримані результати повністю вкладаються в загальноприйняті уявлення про роль атеросклерозу КА в розвитку порушень вінцевого кровообігу, проте варто звернути увагу на наближення частот СН певного ФК у групах $3 \mathrm{KA}^{\mathrm{ATC}>50 \%}$ i Н3КА ${ }^{\text {ATC }>50 \%}$ та факт появи таких пацієнтів у групі ЗКА. Наявність у 96,8\% пацієнтів групи ЗКА підтвердженої СН ФК2 та ФК3 опосередковано свідчить на користь здатності звивистої конфігурації KA спричиняти порушення гемодинаміки у відповідних зонах васкуляризації міокарда та зменшувати функціональні резерви серцевого м'яза при навантаженні. Про порушення кровопостачання серцевого м'яза у пацієнтів зі звивистими КА навіть за умови відсутності ангіографічних ознак атеросклеротичного ураження їх судинної стінки свідчать також результати ЕКГдослідження, які підтверджують анамнестичні дані щодо факту виникнення гострого порушення коронарного

\section{Таблиця 1}

Результати обстеження хворих ішемічною хворобою серия із різним ступенем атеросклеротичного ураження та конфігурації KA (n/\%)

\begin{tabular}{|c|c|c|c|c|}
\hline Діагноз & $\begin{array}{c}3 K A \\
(n=252)\end{array}$ & $\begin{array}{c}3 K A^{\text {ATC } \leqslant 50 \%} \\
(n=92)\end{array}$ & $\begin{array}{c}3 K A^{\text {ATC }>50 \%} \\
(n=244)\end{array}$ & $\begin{array}{c}\text { H3KA } \text { ATC }>50 \%^{(n=816)}\end{array}$ \\
\hline $\mathrm{CH}$ ФК2 & $120 / 47,6$ & $20 / 21,7$ & $24 / 9,8$ & $72 / 8,8$ \\
\hline CH ФK3 & $124 / 49,2$ & $52 / 56,5$ & $168 / 68,9$ & $632 / 77,5$ \\
\hline ПІКС & $60 / 23,8$ & $20 / 21,7$ & $148 / 60,7$ & $476 / 58,3$ \\
\hline $\begin{array}{l}\text { Депресія } \\
\text { сегмента ST } \\
\text { та/або зміни } \\
\text { зубця T }\end{array}$ & $124 / 49,2$ & $76 / 82,6^{*}$ & $240 / 98,0^{* \#}$ & $808 / 99,0^{* \#}$ \\
\hline
\end{tabular}

Примітка: СН - стенокардія напруження; ФК - функціональний клас $\mathrm{CH}$; ПІКС - післяінфарктний кардіосклероз. Статистично достовірні $(\mathrm{p}<0,05)$ відмінності: * - відносно ЗКА; \# -відносно - 3КА ${ }^{\mathrm{ATC} \leq 50 \%}$; при розрахунку відсотка за $100 \%$ обирали кількість пацієнтів окремої групи

кровообігу в пацієнтів досліджуваних груп. Виявлено, що у пацієнтів із відсутніми ангіографічними ознаками гемодинамічно значущого атеросклеротичного ураження КА (групи 3КА та 3KА ${ }^{\mathrm{ATC} \leq 50 \%}$ ) частота розвитку післяінфарктного кардіосклерозу варіює в межах 21,7-23,8\% (табл. 1). Крім того, у пацієнтів груп зі звивистою конфігурацією КА (ЗКА, ЗКА ${ }^{\mathrm{ATC} \leq 50 \%}$ та 3KA ${ }^{\mathrm{ATC}>50 \%}$ ) наявне прогресуюче збільшення частоти появи на електрокардіограмі ознак ішемії міокарда у вигляді депресії сегмента ST та змін зубця T. Водночас частота прояву зазначених ЕКГ-ознак ішемії міокарда в групах $3 \mathrm{KA}^{\mathrm{ATC}>50 \%}$ та НЗКА істотно не відрізняється (табл. 1). Останнє може бути зумовлено збільшенням ролі атеросклеротичного ураження судинної стінки в розвитку ішемії міокарда за наявності стенозу, шо перевищує 50\% діаметра просвіту судини. Вище зазначені факти узгоджуються з результатами проб із дозованим фізичним навантаженням, які виявили, що у $54 \%$ із 56 пацієнтів зі звивистими КА без ангіографічних ознак стенозу (група ЗКА) наявні ознаки порушення перфузії міокарда. Крім того, у 92,8\% пацієнтів цієї досліджуваної групи, яким проводилася стрес-ВЕхоКГ-обстеження, проба була зупинена внаслідок виникнення ознак ішемії міокарда.

Висновки. Звивиста конфігурація вінцевих артерій $є$ фактором, здатним спричинити порушення коронарної гемодинаміки. За відсутності гемодинамічно значущого стенозуючого атеросклеротичного ураження вінцевих судин звивистість КА здатна забезпечити появу клінічних проявів ішемії міокарда, що необхідно враховувати в ранній діагностиці різних форм IXC. Порушення кровопостачання та зменшення функціональних резервів серцевого м'яза імовірно зумовлено збільшенням гемодинамічного опору, який у КА зі звивистою конфігурацією підвищується порівняно з незвивистими судинами за 
рахунок збільшення лінійної довжини та появи місцевого опору. На тлі звивистості КА роль атеросклеротичного ураження судинної стінки КА збільшується відповідно до досягнення гемодинамічної значущості стенозу.

\section{Література}

1. Hendel R. C. Initial Diagnostic Evaluation of Stable Coronary Artery Disease: The Need for a Patient-Centered Strategy / R. C. Hendel, A. Y. Jabbar, I. Mahata // Journal of the American Heart Association. - 2017. - Vol. 6, № 7. - P. e006863.

2. Shaw L. J. Comparative effectiveness trials of imaging guided strategies in stable ischemic heart disease / L. J. Shaw, L. M. Philips, E. Nagel [et al.] // JACC Cardiovasc Imaging. - 2017. - Vol. 10, № 3. - P. 321-334.

3. Han H. C. Twisted Blood Vessels: Symptoms, Etiology and Biomechanical Mechanisms / Hai-Chao Han // J. Vasc. Res. - 2012. - Vol. 49. - P. 185-197.

4. Angina with «Normal» Coronary Arteries [Електронний pecypc] / R. N. Fogoros // Verywell Health. - Режим доступу : https://www.verywell.com/chest-pain-with-normalcoronary-arteries-1745819

5. Chiha J. Gender differences in the prevalence of coronary artery tortuosity and its association with coronary artery disease / J. Chiha, P. Mitchell, B. Gopinath [et al.] // IJC Heart \& Vasculature. - 2017. - Vol. 14. - P. 23-27.
6. Li Y. Clinical Implication of Coronary Tortuosity in Patients with Coronary Artery Disease / Y. Li, C. Shen, Y. Ji [et al.] // PLoS ONE. - 2011. - Vol. 6, Issue 8. - P. e24232.

7. Estrada A. P. D. Coronary tortuosity and its role in myocardial ischemia in patients with no coronary obstructions /A. P. D. Estrada, R. O. Lopes, H. V. Junior // Int. J. Cardiovasc. Sci. - 2017. - Vol. 30, Issue 2. - P. $163-$ 170.

8. Li Y. Coronary tortuosity is associated with reversible myocardial perfusion defects in patients without coronary artery disease / Y. Li, N. F. Liu, Z. Z. Gu [et al.] // Chin. Med. J. - 2012. - Vol. 125, № 19. - P. 3581-3583.

9. Cerqueira M. D. Standardized myocardial segmentation and nomenclature for tomographic imaging of the heart: a statement for healthcare professionals from the Cardiac Imaging Committee of the Council on Clinical Cardiology of the American Heart Association / M. D. Cerqueira, J. S. Wiessman, V. V. Dilsizian [et al.] // Circulation. 2002. - Vol. 105. - P. 539-542.

10. Maçrycorresponding W. Physiological basis in the assessment of myocardial mechanics using speckle-tracking echocardiography 2D. Part II / W. Mądrycorresponding, M. A. Karolczak // J. Ultrason. - 2016. - Vol. 16 (66). P. 304-316.

\title{
The role of tortuous configuration of coronary arteries in the development of clinical manifestations of ischemic heart disease
}

\author{
Y. Lebedieva ${ }^{1}$, M. Grusha ${ }^{2}$ \\ ${ }^{1}$ National M. M. Amosov Institute of Cardiovascular Surgery National Academy of Medical Sciences of Ukraine (Kyiv) \\ ${ }^{2}$ National Medical University named after A. A. Bogomolets (Kiev)
}

In the article we consider the role of tortuous configuration of coronary arteries (CA) in the occurrence of clinical manifestations of ischemic heart disease (IHD) in patients without any angiographic signs of atherosclerotic lesions of the vascular wall and with varying degrees of coronary stenosis. The results of general clinical, electrocardiographic and stress vector-echocardiographic examination of such patients are presented. Evidences of the importance of tortuous configuration of CA in the development of clinical manifestations of myocardial ischemia in case of absence and presence of angiographic signs of hemodynamically significant coronary atherosclerosis is presented. The role of tortuosity of CA in the coronary hemodynamics violation, reducing the functional reserves of the heart muscle and the occurrence of clinical manifestations of myocardial ischemia is demonstrated, which must be taken into account in early diagnosis of various forms of IHD.

Key words: ischemic heart disease, coronary artery tortuosity, coronary hemodynamics violation.

\section{Роль извитой конфигурации коронарных артерий в возникновении клинических проявлений ишемической болезни сердца}

\author{
Лебедева Е. О. ${ }^{1}$, Груша М. М. ${ }^{2}$

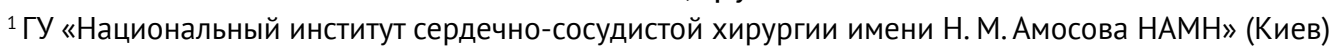 \\ ${ }^{2}$ Национальный медицинский университет имени А. А. Богомольца (Киев)
}

В статье рассмотрена роль извитой конфигурации коронарных артерий (КА) в возникновении клинических проявлений ишемической болезни сердца (ИБС) у пациентов без ангиографических признаков атеросклеротического поражения сосудистой стенки и с разной степенью коронарного стеноза. Представлены результаты общеклинического, электрокардиографического и стресс-вектор-эхокардиографического обследования таких пациентов. Приведены доказательства значимости извитой конфигурационной аномалии КА в развитии клинических проявлений ишемии миокарда при отсутствии и наличии ангиографических признаков гемодинамически значимого атеросклероза коронарных сосудов. Продемонстрирована роль извитости КА в нарушении коронарной гемодинамики, уменьшении функциональных резервов сердечной мышцы и появлении клинических проявлений ишемии миокарда, что необходимо учитывать в ранней диагностике различных форм ИБС.

Ключевые слова: ишемическая болезнь серди, извитость коронарных артерий, нарушение коронарной гемодинамики. 